\title{
Minat Siswa Sekolah Menengah Atas dalam Mengikuti Jong Batak Art Festival IV di Taman Budaya Sumatera Utara
}

\section{The Interest of Students High School in the Jong Batak Art Festival IV in the North Sumatra Cultural Park}

\author{
Erfinaika Siringoringo, Uyuni Widiastuti \& Lamhot Basani Sihombing \\ Program Studi Pendidikan Musik Jurusan Sendratasik \\ Fakultas Bahasa dan Seni Universitas Negeri Medan, Indonesia
}

Diterima: Januari 2019; Disetujui: Mei 2019; Diterbitkan: Juni 2019.

\begin{abstract}
Abstrak
Penelitian ini bertujuan untuk mengetahui minat siswa SMA YP. HKBP Sidorame dalam mengikuti Jong batak Art Festival IV di Taman Budaya Sumatera Utara serta faktor yang memengaruhi minat siswa SMA YP. HKBP Sidorame dalam mengikuti Jong batak Art Festival IV di Taman Budaya Sumatera Utara. Teori yang digunakan dalam penelitian ini adalah teori minat, macam-macam minat, faktor yang memengaruhi, jong batak yang menjelaskan rasa lebih suka dan rasa ketertarikan pada suatu hal atau aktivitas, tanpa ada yang menyuruh. Pada dasarnya minat adalah penerimaan akan suatu hubungan antara diri sendiri dengan sesuatu diluar diri, semakin kuat atau dekat hubungan tersebut maka semakin besar minat. Metode dalam penelitian ini adalah mixed methods. Pengumpulan data dilakukan berdasarkan studi kepustakaan, observasi, dan dukumentasi. Sampel dalam penelitian ini adalah siswa kelas XII IPS 1 yang berjumlah 32 orang. Berdasarkan hasil penelitian yang dilakukan, dapat diketahui bahwa penggunaan angket sebagai instrumen penelitian menunjukkan bahwa siswa berminat mengikuti Jong Batak Art Festival IV namun belum mencapai tingkat tertinggi dalam kategori penilaian, yaitu Sangat Berminat.
\end{abstract}

Kata Kunci: Minat, Siswa, Jong Batak, Art Festival

\section{Abstract}

This study aims to determine the interest of YP high school students. HKBP Sidorame in following Jong Batak Art Festival IV in the North Sumatra Cultural Park and the factors that influenced the interest of YP High School students. HKBP Sidorame in following Jong Batak Art Festival IV in North Sumatra Cultural Park. The theory used in this study is the theory of interest, kinds of interests, influencing factors, jong batak which explains the feeling of being more like and feeling interested in something or activity, without being told. Basically, interest is the acceptance of a relationship between yourself and something outside of yourself, the stronger or nearer the relationship, the greater the interest. The method in this study is mixed methods. Data collection is based on library studies, observation, and documentation. The sample in this study were students of class XII IPS 1 totaling 32 people. Based on the results of the research conducted, it can be seen that the use of questionnaires as research instruments shows that students are interested in participating in the Jong Batak Art Festival IV but have not reached the highest level in the assessment category, which is Very Interested.

Keywords: Interest, Students, Jong Batak, Art Festival

How to Cite: Siringoringo, E. Widiastuti, U. \& Basani, L. (2019). Minat Siswa Sekolah Menengah Atas dalam Mengikuti Jong Batak Art Festival IV di Taman Budaya Sumatera Utara. Gondang: Jurnal Seni dan Budaya, 3 (1): 1-9.

*Corresponding author:

E-mail:erfi12@gmail.com
ISSN 2549-1660 (Print)

ISSN 2550-1305 (Online) 


\section{PENDAHULUAN}

Jong Batak Art Festival IV dilaksanakan pada tanggal 25-28 Oktober 2017. kegiatan ini mengajak sejumlah seniman yang akan berkontribusi dalam acara ini, dan melibatkan sejumlah pelajar untuk mengikuti Acara tersebut. Selain dapat menikmati dan mengapresiasikan bakat, pelajar dan masyarakat semakin apresiatif terhadap budaya dan hendaknya ikut berperan dalam melestarikan budaya melalui acara tersebut. Dalam hal ini identitas serta kecintaan terhadap budaya dapat ditunjukan melalui sikap apresiasi, menampilkan sebuah kreativitas dan dapat berperan serta dalam perkembangan budaya di Sumatera Utara.

Minat pelajar terhadap suatu pertunjukan yang berbau budaya seperti pertunjukan Jong Batak Art Festival kian lama kian ditinggalkan oleh pelajar yang disebabkan masuknya budaya Barat yang lebih modern. Minat bisa timbul karena adanya dorongan dari diri sendiri. Oleh karena itu, disimpulkan bahwa minat itu adalah sikap atau perasaan senang terhadap sesuatu yang diinginkannya. Jika seorang pelajar senang terhadap sesuatu, pelajar tersebut akan berusaha secara terus menerus untuk mendapatkannya. Minat merupakan kesadaran seseorang terhadap suatu objek, orang, masalah, atau situasi yang mempunyai kaitan dengan dirinya.

SMA HKBP Sidorame merupakan salah satu sekolah swasta yang berada di Jl. Dorowati, Kota Medan. SMA HKBP Sidorame merupakan salah satu dari beberapa sekolah yang selalu aktif hadir dalam mengikuti Jong Batak Art Festival. Salah satu faktor yang mendorong pelajar mengikuti Jong Batak Art Festival IV adalah untuk menambah wawasan, pengetahuan, mengembangkan minat dan bakat. Apalagi kalau minat itu selaras dengan bakatnya, maka kekuatannya lebih luar biasa lagi.

Berdasarkan observasi yang telah dilakukan, Jong Batak Art Festival ini sangat baik diadakan karena kegiatan ini mampu memotivasi pemuda/i khususnya Pelajar Kota Medan di Sumatera Utara untuk melestarikan budaya.

\section{METODE PENELITIAN}

Sesuai dengan judul penelitian ini, Minat SMA YP. HKBP Sidorame Dalam Mengikuti Jong Batak Art Festival IV di Taman Budaya Sumatera Utara. Maka lokasi penelitian dilakukan di Sekolah YP.SMA HKBP Sidorame di Kota Medan dan Waktu penelitian dilaksanakan pada bulan Juli-Agustus 2018.

Minat merupakan suatu keadaan di mana seseorang mempunyai perhatian terhadap sesuatu dan disertai keinginan 
untuk mengetahui dan mempelajari maupun membuktikannya lebih lanjut. Minat timbul karena adanya perhatian yang mendalam terhadap suatu obyek, di mana perhatian tersebut menimbulkan keinginan untuk mengetahui, mempelajari, serta membuktikan lebih lanjut. Untuk mengetahui minat tersebut, faktor-faktor yang mempengaruhi minat pada hakikatnya merupakan sebab akibat dari pengalaman. Minat tidak muncul dengan sendirinya akan tetapi ada beberapa faktor yang dapat mempengaruhi minat tersebut yaitu faktor internal dan eksternal.Seberapa besar minat dapat dilihat dari berbagai indikator/aspek mengenai minat yang kemudian diukur dengan pengukuran data melalui pernyataan berupa angket.

Sesuai pernyataan di atas maka kerangka konseptual ini bertujuan untuk menyusun topik penelitian yang berjudul "Minat Siswa SMA YP. HKBP SidorameDalam Mengikuti Jong Batak Art Festival IV di Taman Budaya Sumatera Utara".

Adapun populasi yang terjangkau dalam penelitian ini adalah kelas XII IPS SMA Sidorame Medan. Sampel diambil langsung dari kelas XII IPS SMA Sidorame yang berjumlah 32 siswa yang diambil secara sampling insidental.
Dilihat dari segi cara atau teknik pengumpulan data, maka teknik pengumpulan data dapat dilakukan dengan interview, kuesioner (angket), observasi (Sugiyono, 2006). Pengumpulan data dilakukan dengan cara sebagai berikut. 1) Observasi; 2) Angket; 3) Dokumentasi; 4) Instrument

\section{HASIL DAN PEMBAHASAN}

\section{Minat Siswa mengikuti Jong Batak Art Festival IV}

Menurut Slameto (2010), "Minat adalah suatu rasa lebih suka dan rasa keterikatan pada suatu hal atau aktivitas, tanpa ada yang menyuruh." Pada dasarnya minat adalah penerimaan akan suatu hubungan antara diri sendiri dengan sesuatu diluar diri.semakin kuat atau dekat hubungan tersebut, semakin besar minat.

Menurut Hurlock (1999) dalam Khairani Makmun (2013) minat merupakan sumber motivasi yang mendorong orang untuk melakukan apa yang mereka inginkan bila mereka bebas memilih ketika seseorang menilai bahwa sesuatu akan bermanfaat, maka akan jadi berminat, kemudian hal tersebut akan mendatangkan kepuasan. Ketika kepuasaan menurun, maka minat juga akan menurun. Sehingga minat tidak bersifat permanen, tetapi minat bersifat sementara atau dapat berubah-ubah. 
Sedangkan menurut Crow and Crow (1984) dalam Khairani Makmun (2013) minat dapat menunjukkan kemampuan untuk memberi stimuli yang mendorong individu untuk memperhatikan seseorang, sesuatu barang atau kegiatan, atau sesuatu yang dapat memberi pengaruh terhadap pengalaman yang telah distimuli oleh kegiatan itu sendiri.

Di samping itu menurut Jhon Holland, (2013) dalam Khairul Makmun minat merupakan aktivitas atau tugastugas yang membangkitkan perasaan ingin tahu, perhatian, dan memberi kesenangan atau kenikmatan.

Berdasarkan pendapat tersebut, maka peneliti menyimpulkan bahwa minat merupakan rasa ketertarikan seseorang dan ingin tahu yang lebih dari sesuatu Objek yang diperhatikan sehingga minat dapat menyebabkan seseorang giat melakukan suatu kegiatan menuju ke sesuatu yang telah menarik minatnya.

Seseorang dapat mengungkapkan minat atau pilihanya dengan kata-kata tertentu. Misalnya, seseorang mungkin mengatakan bahwa dirinya tertarik dalam mengumpulkan mata uang logam, perangko dan lain-lain.

Seseorang dapat mengungkapkan minat bukan melalui kata-kata melainkan dengan tindakan atau perbuatan, yaitu ikut serta dan berperan aktif dalam suatu kegiatan. Misalnya, kegiatan olahraga, pramuka, dan sebagainya yang menarik perhatian.

Minat merupakan kecenderungan dalam diri individu untuk tertarik pada suatu objek, kesukaan atau kesenangan akan sesuatu. Minat sangat dibutuhkan oleh siapapun untukmeningkatkan motivasi dan kegairahan dalam melakukan sesuatu atau terhadapobjek tertentu.Dapat dikatakan bahwa minat merupakan indikator keberhasilan anak dalam melakukan suatu hal.

Bagi siswa, minat ini sangat penting.Hal tersebutdikarenakan dapatmenggerakkan perilaku siswa ke arah positif sehingga mampu menghadapi segalatuntunan, kesulitan serta menanggung resiko dalam studinya.Minat dapatmenentukan baik tidaknya dalam mencapai tujuan sehingga semakin besar minat, semakin besar kesuksesan yang dapat diraih oleh seseorang.Minat sebagai faktor batin berfungsimenimbulkan, mendasari dan mengarahkan perbuatan belajar. Seorang yang besarminatnya akan giat berusaha, tampak gigih, tidak mau menyerah serta giatmengikuti setiap kegiatan.Minat dapat meningkatkan motivasi siswa mengikuti kegiatan Jong Batak Art Festival IV di Taman Budaya sehingga siswa dapat memeroleh prestasi yang maksimal. 
Dari hasil penelitian diketahui minat siswa dalam mengikutikegiatan Jong Batak Art Festival IV di Taman Budaya Sumatera Utaraberminat dengan persentase sebesar62,5\%. Hasil tersebut diartikan siswa sudah memiliki minatdan mempunyaiantusias dalam mengikuti kegiatan Jong Batak Art Festival IV di Taman Budaya Sumatera Utara.Hal tersebut dilihat dari hasil analisis data penulis berupa angket, dengan indikator minat siswa dalam mengikuti Jong Batak Art Festival, ketertarikan, perasaan senang, dan bakat siswa dalam hal seni.

Minat seorang anak juga tidak lepas dari berbagai faktor yang memengaruhinya, yaitu faktor internal yang merupakan faktor yang berasal dari diri siswadan faktor eksternal yang merupakan faktor yang berasal dari luar diri siswa, yaitu lingkungansekolah dan lingkungan keluarga. Jika dua faktor ini bersinergi maka minat yang dimiliki siswa akan baik.

\section{Faktor yang Memengaruhi Minat Siswa}

Seseorang menilai minatnya agar dapat diukur dengan menjawab sejumlah pertanyaan tertentu atau urutan pilihannya untuk kelompok aktivitas tertentu. Pertanyaan-pertanyaan disusun dengan menggunakan angket.
Minat tidak muncul dengan sendirinya, terdapat banyak faktor yang menimbulkan minat seseorang terhadap sesuatu yang diminatinya. Faktor-Faktor tersebut adalah sebagai berikut. Faktor internal adalah: 1) Bakat dan Bawaan; 2) Tingkat Perkembangan; 3) Kondisi dan psikis.

Faktor internal atau faktor dari luar merupakan faktor yang terjadi ketika adanya rangsangan-rangsangan yang berpengaruh dalam memberikan sentuhan-sentuhan kejiwaan secara langsung yang dibuat atau sengaja dilakukan untuk menumbuhkan kesadaran, yang nantinya akan membangkitkan perhatian dan minat seseorang. Faktor luar tersebut adalah: 1) Motivasi; 2) Keluarga; 3) Fasilitas; 4) Kebutuhan.

Ada beberapa indikator mengenai minat. Indikator ini disusun berdasarkan aspek minat siswa. Menurut Djamarah (2011), aspek yang dimaksud adalah adanya kesukaan, ketertarikan, perhatian, dan keterlibatan.

Untuk mengetahui berapa besar minat siswa dapat diukur melalui: 1) Kesukaan; 2) Ketertarikan; 3) Perhatian; 4) Keterlibatan

Faktor-faktor yang memengaruhi minat siswa dalam mengikuti Jong Batak Art Festival IV di Taman Budaya Sumatera 
Utara yaitu bakat, tingkat perkembangan, motivasi, kebutuhan, ketertarikan, perasaan senang, dan keluarga.

Seorang anak yang memiliki bakat dalam hal seni serta didukung dengan tingkat perkembangan nya yang baik dalam seni, tentu akan sangat berminat mengikuti kegiatan seperti Jong Batak Art festival ini. Hal tersebut dibuktikan dengan adanya siswa yang berpartisipasi untuk menyukseskan Acara Jong Batak Art Festival IV di Taman Budaya Sumatera Utara. Adapun salah satu kegiatan yang mereka ikuti yaitu tari tortor. Terlihat jelas siswa yang memiliki bakat menari tradisi, berminat untuk menyukseskan acara tersebut dengan bakat yang mereka miliki sedangkan siswa lain yang kurang berbakat dalam hal tari memilih untuk menjadi penonton saja.

Kemudian faktor motivasi.Motivasi merupakan dorongan yang timbul pada diri seseorang secara sadar atau tidak sadar untuk melakukan suatu tindakan dengan tujuan tertentu.Motivasi dapat dipicu oleh beberapa hal, salah satunya adalah teman. Dalam hal ini, peneliti meninjau hasil tes angket siswa yang menunjukkan bahwa masih ada siswa yang terpengaruh oleh ajakan teman. Beberapa siswa menjawab bahwa ajakan teman meninggalkan acara Jong Batak Art Festival IV di Taman Budaya, lebih penting daripada stay menghadiri acara tersebut. Kemudian ada juga yang menyatakan bahwa ia bosan selama acara berlangsung. Dengan begitu dapat disimpulkan bahwa motivasi siswa tersebut tidak memiliki motivasi dan minat yang tinggi dalam mengikuti kegiatan Jong Batak Art Festival IV di Taman Budaya, terlihat dari tidak adanya motivasi dari dalam dirinya untuk benar-benar serius mengikuti acara tersebut.

Faktor kebutuhan juga salah satu cara melihat bagaimana minat siswa. Siswa yang merasa membutuhkan seni dalam hidupnya, yang juga memiliki bakat dalam hal seni, tentu akan senantiasa mengikuti kegiatan bermanfaat Jong Batak Art Festival IV di Taman Budaya. Dengan adanya kegiatan tersebut, maka pengetahuan akan hal seni terutama seni tradisi akan bertambah. Dengan bertambahnya pengetahuan siswa, maka akan semakin mendukung adanya bakat dalam dirinya.Terdapat beberapa siswa yang memiliki bakat seni dalam dirinya, sudah yakin memiliki minat untuk mengikuti kegiatan tersebut.Hal ini ditinjau dengan melihat hasil tes angket yang diisi oleh siswa.

Ketertarikan juga merupakan hal penting lainnya. Anak yang memiliki ketertarikan akan suatu hal atau kegiatan, akan merespon kegiatan tersebut dengan 
positif serta mencari tau bagaimana ia dapat mengembangkan dirinya melalui ketertarikannya tersebut. Jika seorang anak tidak memiliki ketertarikan akan seni, maka akan sulit menumbuhkan minatnya untuk mengikuti kegiatankegiatan yang bersangkutan dengan seni, begitupula dengan siswa-siswi kelas XII IPS-1. Melalui hasil tes angket, peneliti dapat melihat seberapa tertarik dan antusias siswa-siswi tersebut mengikuti kegiatan Jong Batak Art Festival IV di Taman Budaya.Masih ada siswa yang hanya memiliki sedikit saja ketertarikan untuk mengikuti kegiatan tersebut.Hal itu dilihat dari hasil tes angket beberapa siswa yang masih terpengaruh oleh ajak teman untuk meninggalkan acara tersebut. Selain itu, masih ada siswa yang mengikuti kegiatan Jong Batak Art Festival IV di Taman Budaya hanya karena disuruh oleh guru.

Selain ketertarikan, ada faktor perasaan senang. Jika seorang siswa memiliki perasaan senang, maka siswa tersebut merasa nyaman dan tenu memiliki minat yang tinggi untuk mengikuti kegiatan Jong Batak Art Festival IV di taman budaya sumatera utara.

Selain itu, dorongan guru, orang tua, teman, cukup memengruhi minat siswa mengikuti Jong Batak Art Festival IV.
Dorongan seorang pendidik dapat menimbulkan minat siswanya dengan memberi arahan, membantu mengembangkan bakat, dan memberi keyakinan bahwa kesenian tradisi bukanlah hal yang membosankan, melainkan suatu kebudayaan yang memiiki nilai dan harus dilestarikan. Begitupula dengan dorongan dari orangtua yang sangat diperlukan oleh siswa untuk menimbulkan minat siswa. Orangtua mempunyai peran penting untuk selalu mengingatkan anak-anaknya bahwa budaya merupakan warisan yang harus dilestarikan dan diapresiasi.Dan dorongan teman, merupakan faktor eksternal lainnya yang sangat memengaruhi minat seorang anak. Hal tersebut terjadi karena pada umumnya anak-anak menghabiskan waktu bermain dengan temannya, sehingga faktor lingkungan ataupun teman menjadi salah satu pembentuk kepribadian dan minat seorang anak.

\section{SIMPULAN}

Siswa berminat mengikuti Jong Batak Art Festival IV namun belum mencapai tingkat tertinggi dalam kategori penilaian, yaitu Sangat Berminat. Faktor-Faktor yang memengaruhi minat siswa dalam mengikuti Jong Batak Art Festival IV di Taman Budaya Sumatera Utara yaitu kurangnya rasa senang terhadap acara seni, tidak memiliki bakat, terpengaruh 
ajakan teman, dan memilih hadir karena disuruh guru. Faktor tersebut berpengaruh pada tingkatan minat siswa SMA kelas XII IPS YP. HKBP Sidorame.

\section{DAFTAR PUSTAKA}

Ardhana, A.R. (2016). Minat Remaja Terhadap Genre Musik Punk di Kota Kisaran Kecamatan Kisaran Timur. Skripsi

Crow and Crow. (1984). Psikologi Belajar, Terbitan (KDT)

Djamarah. (2011). Psikologi Belajar.Rineka Cipta Harlock (1999) Psikologi Belajar, Terbitan (KDT

Cwettherrington, H. (1983) Psikologi Belajar, Terbitan (KDT)

Holland, J. (2013). Psikologi Belajar, Terbitan (KDT)

Khairani Makmun .2013. Psikologi Belajar, Terbitan (KDT)

Manurung. (2012). Metodologi Penelitian.
Pamungkas, M.Z. (2015). Pengaruh Event Festival Budaya Terhadap Citra Kabupaten Purwakarta Sebagai Kota Budaya (Survey terhadap pengunjung Event festival budaya di purwakarta)

Agus, N. (2013). Jong Batak Bond, Museum Sumpah Pemuda

Yudana, N. (2014). Minat Siswa Kelas VIII SMP Negeri 1 Pangadegan terhadap jenis musik. Skripsi

Slameto. (2010). Belajar dan Faktor-Faktor Yang Mempengaruhi.

Sugiyono. (2012). Metode Penelitian Pendidikan, Pendekatan Kuantitatif, Kualitatif, dan R \& D. Bandung: Alfabeta.

Sugiyono. (2016). Metode Penelitian Pendidikan, Pendekatan Kuantitatif, Kualitatif, dan R \& D. Bandung: Alfabeta.

Syahrum. (2014). Metode Penelitian Kuantitatif. Cita Pustaka Media

Wahyudi. (2016). Minat Remaja Terhadap Orkes Melayu Di Kecamatan Marbau Kabupaten Labuhanbatu Utara.

Budiarti, Y. (2011). Minat belajar siswa terhadap mata pelajaran bahasa Indonesia (studikasus di SMA PGRI 56 Ciputat). 